\title{
Bank Interest Margin, Multiple Shadow Banking Activities, and Capital Regulation
}

\author{
Jyh-Horng Lin ${ }^{1}$, Shi Chen ${ }^{2}$ (D) and Fu-Wei Huang ${ }^{3, *(D)}$ \\ 1 Department of International Business, Tamkang University, New Taipei City 25137, Taiwan; \\ lin9015@mail.tku.edu.tw \\ 2 School of Economics, Southwestern University of Finance and Economics, Chengdu 611130, China; \\ chenshi@swufe.edu.cn \\ 3 Department of Management Sciences, Tamkang University, New Taipei City 25137, Taiwan \\ * Correspondence: kwala.wei@mail.tku.edu.tw; Tel.: +886-921-824-347
}

Received: 6 June 2018; Accepted: 26 June 2018; Published: 3 July 2018

\begin{abstract}
In this paper, we develop a contingent claim model to evaluate a bank's equity and liabilities that integrates the premature default risk conditions with loan rate-setting behavioral mode and multiple shadow banking activities under capital regulation. The barrier options theory of corporate security valuation is applied to the contingent claims of a bank. The barrier reports that default can occur at any time before the maturity date. We focus on a type of earning-asset portfolio, consisting of balance-sheet banking activities of loans and liquid assets and shadow banking activities of wealth management products (WMPs) and entrusted loans (ELs). The optimal bank interest margin, i.e., the spread between the loan rate and the deposit rate, is derived and analyzed. The results provide an alternative explanation for the decline in bank interest margins, which better fits the narrative evidence on bank spread behavior under capital regulation in particular during a financial crisis. Raising either WMPs or ELs leads to a transfer of wealth from equity holders to the debt holders, and hence increases the deposit insurance liabilities. We also show that the multiple shadow banking activities of WMPs and ELs captured by scope equities may produce superior return performance for the bank. Tightened capital requirements may reinforce the superior return performance by a surge in shadow banking activities that makes the bank less prudent and more prone to risk-taking at a reduced margin, thereby adversely affecting banking stability. We demonstrate that financial disturbance may be created because of the potential for shadow banking activities to spill over to regular banking activities and damage the real economy.
\end{abstract}

Keywords: wealth management products; entrusted loans; bank interest margin; capital regulation

JEL Classification: G01; G21; G28

\section{Introduction}

Commercial banks are institutions that mainly engage in two distinct types of lending and deposit-taking activities, and provide liquidity and risk transformation functions with which they generate income. The bank interest margin, i.e., the spread between the loan rate and the deposit rate, is one of the principal elements of bank cash flows and after-tax income (Wong 2011), and is often used as a proxy for the efficiency of financial intermediation (Saunders and Schumacher 2000). The topic of bank interest margin has recently attracted great attention since banks in many countries have experienced a gradual decline in interest margins over the past decades due to global financial deregulation (Arnold and van Ewijk 2012). Considerable research effort has been put toward explaining 
low interest margins by a strong focus on competitive conditions. ${ }^{1}$ Competition generally erodes income, in explanation of deteriorating bank interest margins in the regular banking environment. Our paper seeks to qualify this chain of causality, which runs from competition to lower bank interest margins to shadow banking activities. ${ }^{2}$ This can be motivated based on an off-balance-sheet argument in the spirit of Plantin (2015): The banking system now features two components of equal importance-regular banks and the shadow banking system. We propose an alternative explanation for the decline in bank interest margins, which, in our view, better fits the narrative evidence on bank spread behavior under capital regulation in particular during a financial crisis. Given the view, the issue of the effects shadow banking activities has on bank interest margin, deposit insurance, liabilities, and scope equities boils down to an important question, one that we confront in this paper.

Shadow banking is huge globally, accounting for about $25 \%$ of total money transfers between savers and borrowers worldwide. Overviews of the shadow banking system are provided by Pozsar (2008), who catalogues different types of shadow banks and describes the asset and funding flows within the system, and Adrian and Shin (2009), who focus on the role of security brokers and dealers in the system, and discuss implications for financial regulation. This paper focuses on different shadow banking products in the growth of shadow banking system, having greatly increased the effective leverage on loans to the market and the amount of money-like liabilities backed by these loans. Specifically, assets funded by wealth management products (WMPs) and entrusted loans (ELs), having grown relative to other shadow banking components in China, are two key instruments in shadow banking transactions that concern bank managers (Jiang 2015). WMPs are investment products that provide a return based on the performance of a pool of underlying assets, and ELs are loans made on behalf of large corporations, using banks as intermediaries (Lu et al. 2015). Elliott et al. (2015) point out the significantly changing scales of ELs at RMB 328 billion in 2003, 3.42 trillion in 2010, and 8.55 trillion in 2013. Funke et al. (2015) show that WMPs increased from RMB 2.8 trillion to 12.2 trillion between 2010 and 2014Q1, and the average trust yields were significantly higher than average bank lending rate since 2014Q1. One goal of this paper is to theoretically examine the effects of WMPs and ELs on the optimal bank interest margin. Perhaps, the significant flow of business into shadow banking WMPs and ELs is effectively "bank loans in disguise", where a bank is at the core of the transaction and takes the great bulk of the risks and rewards, but pays non-banks to participate in order to avoid regulatory constraints and costs (Elliott et al. 2015).

Next, we turn our attention to understanding the effect of bank asset portfolio focus versus diversification on the bank's equity return. A fundamental implication of portfolio theory is that diversification across alternative business activities can lead to smoother overall returns and, thus, a lower portfolio risk. Traditional arguments, for example, based on Diamond (1984) and Winton (1999) suggest that banks should be as diversified as possible. However, Acharya et al. (2006) find that loan portfolio diversification is not guaranteed to produce superior performance and greater safety for banks. Stiroh and Rumble (2006) also show that extension of banking to nonbanking activities (i.e., insurance services) provides no diversification benefits of financial services holding companies. Given the divergent views in the literature, we argue that the issue of focus versus diversification has not been addressed thoroughly in a shadow banking context for banks, although it has a long history in the corporate finance literature. The primary difference between our model and these papers is that we consider the effects of expansion of the banking enterprise into shadow banking activities such as WMPs and ELs. This insight is an important aspect of bank diversification management since shadow

1 For papers that explain deteriorating bank interest margins, see for instance, Valverde and Fernández (2007), and Lepetit et al. (2008), among others.

2 Adrian and Ashcraft (2012) demonstrate that credit intermediation on the balance sheets of commercial banks does not constitute shadow banking activities. However, commercial banks can be involved in shadow banking activities since they can provide credit and liquidity lines to shadow bank entities through a conduit system. Commercial banks in turn are owned by bank holding companies. The bank we analyze in this paper can be simply viewed as an institution of a bank holding company. 
banking, in some form or another, is expected to be an important part of the financial system for the foreseeable future (Pozsar et al. 2013). Hence, from a policy standpoint, it is interesting to ask whether the bank benefits or gets hurt from multiple shadow banking diversification of its asset portfolio.

Toward that end, this paper takes the model of Episcopos (2008) as its point of departure. The main contribution is twofold. First, Episcopos (2008) proposes a new methodology for bank capital regulation based on the barrier option framework of Brockman and Turtle (2003). Second, the model of Episcopos (2008) is one of the first to take the credit risk of the insurer into account in the economic valuation of bank liabilities. However, the model omits two key aspects of the behavior of financial intermediation. First, the shadow-banking activities conducted by the bank is ignored. As argued by Adrian and Ashcraft (2012), regulatory reforms remain thus far largely silent on many aspects of shadow banking. Second, Episcopos (2008) assumes that the loan market faced by the bank is perfectly competitive so that quantity-setting is the relevant behavioral model in the market. The assumption is not applicable to the loan market since such a market is highly concentrated where intermediaries set rates and face random loan levels ( $\mathrm{Li}$ and Lin 2016). The authors aim to encompass those two omissions and reintroduce the elements of shadow banking products and bank spread behavior (loan rate-setting behavior) to the model of Episcopos (2008). This extension opens for a wide range of interesting analyses in relation to the issues of bank interest margin determination, bank liabilities, and multiple shadow banking activities.

Capital regulation and deposit insurance are two key bank regulation issues that concern bank managers and regulators. Berger and Bouwman (2013) demonstrate that public outcries for more bank capital tend to be greater after financial crises, and post-crisis reform proposals tend to focus on how capital regulation should adapt to prevent future crises. ${ }^{3}$ Iftikhar (2015) finds empirical evidence that financial reforms and financial liberalization significantly enhance the likelihood of financial fragility, while strong banking regulations and supervision have an inverse relationship with financial fragility. Plantin (2015) further studies the optimal capital regulation of banks in the presence of a shadow banking sector. In addition, banking is an ideal environment for the barrier option model because the Federal Deposit Insurance Corporation (FDIC), as a regulator and insurer, can control the barrier in a very direct manner by the power vested in it by the FDIC Improvement Act (FDICIA) (Episcopos 2008). As an insurer, the FDIC maintains the deposit insurance fund and is responsible for controlling risk to the fund. As a receiver, the FDIC has a fiduciary obligation to all stakeholders of the failing bank.

In light of previous work, the purpose of this paper is to develop a contingent claim model to evaluate a bank's equity and liabilities that integrates the premature default risk conditions with loan rate-setting behavioral mode and multiple shadow banking activities under capital regulation. ${ }^{4}$ The results of all these analyses can be summarized as follows. First, we show that the optimal bank interest margin reacts negatively to an increase in WMPs, an increase in ELs, or an increase in the capital-to-deposits ratio, but a decrease in barrier. Our theory proposes an alternative explanation, focusing on shadow banking activities of WMPs and ELs, for the decline in bank interest margin in the recent literature. Shadow banking activities as such make the bank less prudent and more prone to loan risk-taking, thereby adversely affecting banking stability. Second, we also find that an increase

3 The recent financial crisis has underlined the importance of analyzing the link between bank equity capital and financial stability. Berger and Bouwman (2013) find that capital enhances the performance of medium and large banks primarily during banking crises. Several related papers, for example, Kashyap et al. (2008), Acharya et al. (2012), and Hart and Zingales (2011) document that social efficiency can be improved by requiring banks to operate with more capital, especially during financial crises. However, literature has pointed out some negative consequences of more capital (e.g., Aiyar et al. 2014; Jiménez et al. 2017; Osborne et al. 2012).

4 Our model is fundamentally based on Merton (1974) contingent-claim approach to financial intermediaries. We adopt the option pricing framework along the lines of Ronn and Verma (1986), Brockman and Turtle (2003), and Episcopos (2008) for the valuation of the equity return and the equity risk of a bank (our model and the relevant literature are based on a similar modeling approach from Merton (1974). The barrier option theory of corporate security valuation is applied to the contingent claims of the bank (Episcopos 2008); the work of Ronn and Verma (1986) with an application of Episcopos (2008) is used to value the bank's equity risk, and the framework of Brockman and Turtle (2003) is utilized to model the default risk in the bank's equity return. 
in WMPs, ELs, barrier, or the capital-to-deposits ratio has a positive effect on the bank's liabilities. Third, it is shown that multiple shadow banking diversification efforts may be guaranteed to produce superior return performance but less safety for the bank. Tightening capital requirements may spur a surge in the shadow banking activities of WMPs and ELs that lead to larger risk-taking and liabilities for the bank. Shadow banking involvement as such may be a threat of contagion in the banking system of the economy. Our argument provides an alternative explanation for the collapsed shadow banking during the financial crisis of 2007-2009 (Adrian and Ashcraft 2012). As a result, we suggest that the government should directly regulate shadow credit intermediation because of the potential for shadow bank distress to spill over to other financial institutions and damage the real economy.

This paper is organized as follows. Section 2 illustrates the related literature. Section 3 delineates a contingent claim to the market valuation of a bank's equity, liabilities, and scope equities. Section 4 derives the optimal bank interest margin and further some comparative static results. Section 5 presents a numerical analysis to explain the intuition of the comparative static results. The final section concludes the paper.

\section{Related Literature}

Our theory of shadow banking activities is related to three strands of the literature. As mentioned in the Introduction, with global financial deregulation and the increase in disintermediation, banks faced high competition and then suffered a tremendous decrease in interest margins and profitability on traditional intermediation activities. Our paper is related to the literature on the explanation of lower interest margins. Examples include Valverde and Fernández (2007); Lepetit et al. (2008); Arnold and van Ewijk (2012) and Rahman et al. (2017).

Valverde and Fernández (2007) argue that most literature on bank margins has primarily focused on interest margins; however, interest margins are only a part of the picture due to the increasing share of non-traditional activities in total bank incomes. The authors develop a multiple-out framework and demonstrate that the relationship between bank interest margins and market power varies significantly across bank specialization. Lepetit et al. (2008) argue that banks reacted to the financially competitive environment by diversifying into new activities, which reallocated their income structure by reducing the importance of their traditional banking activities. The authors study the impact on the lending rate of the expansion of financial intermediaries beyond traditional banking activities of deposit funded loans and towards non-interest-income activities. One of their findings is that higher income share from commissions and fees is associated with lower margins and loans spreads. Arnold and van Ewijk (2012) investigate a chain of causality, which runs from bank competition to low interest margins to new banking activities. They propose a "quest-for-growth" explanation for the decline in bank interest margins in many developed countries, which better fits the empirical evidence on bank behavior in the run-up to the credit crisis. In particular, the authors document a significantly positive impact of relationship banking on bank interest margins. Rahman et al. (2017) find robust evidence that more efficient banks hold higher capital and charge lower financial intermediation costs (and hence lower bank margins). The authors also observe that on average, banks increased the cost of financial intermediation during the crisis, however, greater efficiency helped banks to not charge higher intermediation costs. Overall, the main contribution of these papers is alternative explanations for the decline in bank interest margins. However, their studies focus only on traditional balance-sheet banking activities, and ignores shadow banking activities, which have also played a prominent role in discussions on intermediary behavior (Plantin 2015). While we also examine bank interest margin, our focus on the aspects of shadow banking activities takes our analysis in a different direction.

Shadow banking literature to our work is most directly related is that on conformity. Examples are Mandel et al. (2012); Copeland (2012); Bord and Santos (2012); Plantin (2015) and Li and Lin (2016).

Mandel et al. (2012) develop a detailed analysis of commercial banks' sponsorships of shadow banking activities. Copeland (2012) concludes that the shadow banking activities of bank holding companies have been increasing over time and represent a significant share of their total earnings. 
Bord and Santos (2012) point out that the share of loans sold to shadow banking activities has increased significantly_from less than 10\% in 1993 to over 30\% in 2007. Plantin (2015) supports the argument that the large growth of shadow banking activities has been driven by tightening capital regulation. $\mathrm{Li}$ and Lin (2016) suggest that relaxing capital requirements may lead to superior performance and greater safety for the bank carrying on shadow banking activities. The fundamental insight shared by these papers is that conformity is generated by a desire to distinguish oneself from the shadow banking type, with which one wishes not to be identified. In this paper, we follow Adrian and Ashcraft (2012) and consider a shadow bank internal to the bank holding company (the bank in the paper as mentioned previously) that owns a wealth management unit with a market mutual fund. What distinguishes our work from this literature is our focus on the commingling of multiple shadow banking activities with bank interest margin management, and, in particular, the emphasis we put on the interaction between bank spread behavior and shadow banking activities under capital regulation.

In the face of the costs that the 2008 banking crisis has created for the world economy, reform proposals tend to focus on how capital regulation should adapt to prevent future crisis (Kashyap et al. 2008; Acharya et al. 2012; Hart and Zingales 2011). However, these regulatory reforms remain thus far largely silent on many aspects of shadow banking (Gorton and Metrick 2010; Adrian and Ashcraft 2012; Lu et al. 2015).

Plantin (2015) shows that tightening capital requirements may increase shadow banking activities that lead to an overall larger risk on the money-like liabilities of the regular and shadow banking institution. Li and Lin (2016) study bank interest margin when the bank conducts regular lending and shadow-banking entrusted lending activities under capital regulation. The authors find that relaxing regulatory capital requirements may produce superior return performance and greater safety for the bank carrying on shadow-banking entrusted loans. Although the paper also focuses on capital regulation, the primary difference between our model and these papers is that we consider the effects of capital regulation on bank interest margin in the multiple shadow banking activities environment.

\section{The Model}

This section mainly consists of three parts. The first part reviews the basic model of Episcopos (2008) succinctly, and more importantly, loan rate-setting features are introduced to describe the effect of the different shadow banking activities on the optimal bank interest margin. The second part focuses on the valuation of the bank's liabilities. The last part models a measure of the magnitude of scope equities to evaluate the efficiency of multiple shadow banking activities.

\subsection{Bank Equity}

In order to get closed-form, tractable solutions, several simplifying assumptions will be made throughout the paper. (i) Assume that investors and regulators have risk-neutral preferences toward risk. Our equity development based on risk-natural preferences has important repercussions for bank interest margin determination. (ii) Competitive markets are assumed for regular and shadow banking assets, except that the loan market faced by the bank is imperfectly competitive. This assumption implies that the bank exercises some monopoly power in its loan market (Wong 1997; Li and Lin 2016). ${ }^{5}$ Financial markets are assumed to be complete in the sense that any financial claim can be replicated in the market place by a combination of other financial assets. Based on this assumption, market determined values for financial claims on the bank's asset portfolio can be derived. (iii) The regulation period is assumed to be fixed. For example, if the FDIC seizes the assets of a bank, it will continue to manage them at least until the end of the regulation period. (iv) It is assumed that the FDIC

5 Wong (1997) and Li and Lin (2016) assume a presentative banking firm with optimization behaviors. The bank has some market power in its lending activities. When the bank makes a loan to a firm, it gathers the firm's specific information to assess the riskiness of the loan and determine the loan rate. The details of what potentially derive loan demand, in particular, the non-price factors, are not crucial for our research purposes, so this simple reduced form is sufficient. 
monitors the bank continuously, with no error and at no cost. There are no bankruptcy costs as well. The assumption of no insurance premium is made in order to isolate the value of early intervention by the regulators (Episcopos 2008).

In the model, we consider that the bank makes decisions in a single period horizon with two dates, 0 and $1, t \in[0,1]$. At $t=0$, the bank has the following balance sheet in its regular banking activities:

$$
L+B=D+K
$$

where $L>0$ is the amount of loans, $B>0$ is the quantity of liquid assets, such as bonds, $D>0$ is the amount of deposits, and $K>0$ is the stock of capital equity. In the balance-sheet banking activities, the bank's loans belong to a single homogenous class of fixed-rate claims that mature at $t=1 .^{6}$ The demand for loans faced by the bank is governed by a demand function $L\left(R_{L}\right)$ with the condition of $\partial L / \partial R_{L}<0$, where $R_{L}>0$ is the loan rate set by the bank. Loans are risky in that they are subject to non-performance because the bank faces credit risk and does not know ex ante what proportion of its loan repayments will perform. The liquid assets held by the bank during the period can earn the security-market interest rate of $R>0$. The balance-sheet assets at $t=0$ are financed partly by deposits. The supply of deposits faced by the bank is perfectly elastic at a deposit market rate of $R_{D}>0$. Equity capital held by the bank is tied by regulation to be a fixed proportion $q$ of the bank's deposits, $K \geq q D$ (VanHoose 2007). When the capital constraint is binding, the bank's balance sheet of (1) can be rewritten as $L+B=K(1 / q+1)$. This is a binding case where $R$ is sufficiently larger than $R_{D}$ (Wong 1997), implying that the bank would like to rely on deposits rather than on equity capital to finance assets. Our model focuses on the case.

The shadow banking system, the shadow credit intermediation process, is largely organized around securitization and wholesale funding. Loans and mortgages are securitized and thus become tradable products. Funding is conducted in capital markets through instruments such as commercial paper and repos. Savers hold money market balances instead of deposits with banks (Pozsar et al. 2013). In addition to balance-sheet banking activities, the bank can also create WMPs by offering investors the chance to pony up short-term money against a single loan. ${ }^{7}$ We assume that the bank carries the amount of WMPs, $M \geq 0$, during the period, and can earn the market interest rate of WMPs, $R_{M}>0$. The bank cannot invest funds in non-standard assets that exceed $0<\alpha<1$ of the value of its outstanding of WMPs by regulation (Lu et al. 2015). The bank can hold the rest of the funds $(1-\alpha) M$ to earn the security-market interest rate of $R$ in order to capture the opportunity cost of the funds during the period. We assume the condition of $R_{M}>R$ since the bank as an investor bears the investment risk of $\alpha M$ without an explicit guarantee legally. The bank is also assumed to conduct shadow-banking ELs. There are entrusted loans $Q \geq 0$ made by a firm (trustor) in the non-financial economy that is run through the bank (trustee) for legal reasons, but with the bank indemnified from the credit risk of the borrower by the trustor (Elliott et al. 2015). The fund is lent through the bank to the borrower at a specified interest rate $R_{Q}>0$ as instructed by the trustor.

The bank can be involved in shadow banking activities by the way of internal management (Adrian and Ashcraft 2012). ${ }^{8}$ The total assets to be financed at $t=0$ are $L+B+\alpha M+Q$. In addition

6 The bank accepts deposits and chooses the amount of the loans at the beginning of the period $t=0$. We adopt the barrier option framework of Brockman and Turtle (2003) for corporate security valuation. The valuation formula for a European down-and-out call option assumes the options can only be exercised on the expiration date $t=1$. The single period horizon also implies the bank regulation period is fixed Episcopos (2008). The assumption of a fixed regulation period is followed in the deposit insurance literature (Merton 1977; Ronn and Verma 1986).

7 As pointed out by Jiang (2015), Chinese shadow banking instruments mainly fall into two categories, WMPs and ELs. WMPs are investments that offer fixed rates of return well above regulated interest rates for deposits and are often used to fund investments in sectors where bank credit is restricted (Perry and Weltewitz 2015). ELs simply imply loans extended between companies, which often use banks or similar financial institutions as an intermediary (Jiang 2015). Our model focuses on these two shadow banking products.

8 Also see Mandel et al. (2012) as mentioned in the previous section. 
to deposit liabilities, the WMPs are also a portion of total deposits. Investors want a higher return rate of $R_{P}$ of WMPs than $R_{D}$ (Lu et al. 2015). Corporate deposit substitutes, usually invested via the inter-bank market, would need to be considered as well. However, the great bulk of the funding is still in the form of traditional bank deposits. Our model assumes $D>M$. Alternatively, the bank acts the trustee and helps collect the principal with interest $\left(1+R_{Q}\right) Q$ from the borrower on the behalf of the trustor. The bank charges a commission premium of $m>0$ per dollar of ELs (Lu et al. 2015).

With all the assumptions in place, by applying Episcopos (2008), the market value of equity can be assessed. Our framework for option pricing valuation is based on a path-dependent, barrier option model. Path dependence may exist because bank equity can be knocked out whenever a legally binding barrier is breached. A direct implication of this framework is that the market value of the bank's equity can be viewed as a down-and-out call $(D O C)$ option on the market value of the bank's underlying assets. The market value of the bank's assets, denoted by $V$, is assumed to follow a geometric Brownian motion of the form:

$$
d V=\mu V d t+\sigma V d W
$$

where

$$
V=\left(1+R_{L}\right) L+\alpha\left(1+R_{M}\right) M+\left(1+R_{Q}\right) Q,
$$

and where $V$ is identified as the repayment value from the bank's risky earning-asset portfolio, including repayments from loans, WMPs, and ELs, respectively, with an instantaneous drift $\mu$, and an instantaneous volatility $\sigma$. A standard Wiener process is $W$ where the value of $V$ is assumed to follow a lognormal distribution.

We denote by $Z$ the book value of the debt at $t=0$, that has maturity at $t=1$. Specifically, this model defines the debt as net-obligation payments, including (i) payments to depositors net of repayments from the liquid-asset investment in regular-banking activities, (ii) payments to investors of the WMPs net of repayments from a portion of the products invested in the liquid-asset market in shadow-banking activities, and (iii) payments to the trustor net of the commission premium collected by the bank in shadow-banking activities. ${ }^{9}$ Notice that although term (i) is subject to the balance sheet of (1), terms (ii) and (iii) is not. $Z$ plays the role of the strike price of the DOC, since the market value of equity can be thought of as a DOC option on $V$ when default can occur at any time before the maturity date.

The market value of equity, DOC, will then be given by the Merton (1973) formula for barrier options:

$$
D O C=S C-D I C,
$$

where

$$
\begin{gathered}
S C=V N\left(d_{1}\right)-Z e^{-\delta} N\left(d_{2}\right), \\
D I C=V\left(\frac{H}{V}\right)^{2 \eta} N\left(b_{1}\right)-Z e^{-\delta}\left(\frac{H}{V}\right)^{2 \eta-2} N\left(b_{2}\right), \\
Z=\left\{\frac{\left(1+R_{D}\right) K}{q}-(1+R)\left[K\left(\frac{1}{q}+1\right)-L\right]\right\}+\left[\left(1+R_{P}\right) M-(1-\alpha)(1+R) M\right]+\left[\left(1+R_{Q}\right) Q-m Q\right], \\
\delta=R-R_{D}, H=\beta Z, 0<\beta<1, \eta=\frac{\delta}{\sigma^{2}}+\frac{1}{2}, \\
d_{1}=\frac{1}{\sigma}\left(\ln \frac{V}{Z}+\delta+\frac{\sigma^{2}}{2}\right), d_{2}=d_{1}-\sigma, \\
b_{1}=\frac{1}{\sigma}\left(\ln \frac{H^{2}}{V Z}+\delta+\frac{\sigma^{2}}{2}\right), b_{2}=b_{1}-\sigma,
\end{gathered}
$$

and where $\delta$ is the compounded risk-free spread rate, $H$ is the value of the bank's assets that triggers bankruptcy (this is the barrier or knock-out value of the bank), and $N(\cdot)$ is the standard normal cumulative distribution function. For tractability, it is assumed that in the default event, no rebate

9 The administrative costs and the fixed costs are omitted for simplicity because adding this complexity affects none of the qualitative results. 
is paid to the bank's owners, and the default barrier level $H$ is assumed to be proportional to the net-obligation payments $Z$ by a constant barrier-to-debt ratio $\beta .{ }^{10}$ The term SC in (3) is recognized as the expected bank value and present value of the debt payments using the standard call option view of the bank. The term DIC is a related path-dependent option of the down-and-in call that is activated only if the barrier is breached. It is seen easily that the DOC option is a wider class than the SC option because as $H$ approaches zero in (3), the DIC vanishes, and we arrive at the usual Black and Scholes (1973) call option price that captures the bank's equity.

\subsection{Bank Liabilities}

As far as liabilities, the final payoffs of (3) indicate that the bank's liabilities can be priced as follows: ${ }^{11}$

$$
L i a=Z e^{-\delta}-P U T+D I C,
$$

where

$$
P U T=Z e^{-\delta} N\left(-d_{2}\right)-V N\left(-d_{1}\right),
$$

and where PUT denotes the price of the equity holders' put to default, that is, to walk away from their guaranteed commitments. The first two terms on the right-hand side of (4) represent the Black and Scholes (1973) value of debt. The first term is the discounted value of the net-obligation payments. The second term is the standard put option or the value of the fair insurance needed in order to make the net-obligation payments risk free. The third term represents the value of the down-and-in call. Debtors would cash in on this option if they were able to jointly seize the assets of the bank when the bank's assets $V$ dropped to the barrier $H$.

Next, by applying the option pricing framework (see Brockman and Turtle 2003), the implied failure probability from the DOC option model of (3) can be assessed. The failure or default probability is the probability that the bank's assets will be less than the book value of its liabilities. The valuation (3) implies a risk-neutral failure probability over the interval from $t \in[0,1]$ that we can write as:

$$
P_{d e f}=N\left(c_{1}\right)+e^{c_{2}}\left(1-N\left(c_{3}\right)\right)
$$

where:

$$
c_{1}=\frac{1}{\sigma}\left(\ln \frac{\alpha Z}{V}-\sigma+\frac{\sigma^{2}}{2}\right), c_{2}=\frac{2\left(\sigma-\sigma^{2} / 2\right)}{\sigma^{2}} \ln \frac{\alpha Z}{V}, c_{3}=-\frac{1}{\sigma}\left(\ln \frac{\alpha Z}{V}+\sigma-\frac{\sigma^{2}}{2}\right) .
$$

This failure probability is used in the following subsection when the formula of the scope equities is developed in our model.

\subsection{Scope Equities}

Our model attempts to ascertain whether or not shadow banking extension is value-enhancing or value-destroying to the bank. Our approach exploits the consolidation across loans, WMPs, and/or ELs. Specifically, we apply Baumol et al. (1982) and define "scope equities", which demonstrate a primary phenomenon that identifies that the shadow banking extension of the bank can be broken up into several alternatives without any decrease in equity, perhaps even with some increment. In the

10 Merton (1973) considers a barrier as an exponential function of time. For simplicity, we follow Brockman and Turtle (2003) and consider only the case of a constant barrier.

11 Episcopos (2008) develops a model of bank liability with exactly this structure. 
model, we develop the following three measures of the magnitude of scope equities in the shadow banking extension valuation:

$$
\begin{gathered}
S E_{M 0}=\frac{Y_{M 0}-Y_{00}}{Y_{M 0}} \text { extension into WMPs only, } \\
S E_{0 Q}=\frac{Y_{0 Q}-Y_{00}}{Y_{0 Q}} \text { extension into ELs only, } \\
S E_{M Q}=\frac{Y_{M Q}-Y_{00}}{Y_{M Q}} \text { extension into WMPs and ELs, }
\end{gathered}
$$

where:

$$
\begin{gathered}
Y(M \geq 0, Q \geq 0)=\left(1-P_{\text {def }}(M \geq 0, Q \geq 0)\right) D O C(M \geq 0, Q \geq 0), \\
Y_{M 0}=Y(M>0, Q=0), Y_{0 Q}=Y(M=0, Q>0), \\
Y_{M Q}=Y(M>0, Q>0), Y_{00}=Y(M=0, Q=0) .
\end{gathered}
$$

The term $Y$ can be identified as the risk-adjusted equity value, i.e., the equity value deflated by the default probability of the bank's equity return. The terms $Y_{M 0}, Y_{0 Q}$, and $Y_{M Q}$ can be identified as the risk-adjusted equity values when the extension into WMPs or/and ELs is considered, and $Y_{00}$ is treated as the benchmark equity value when WMPs or ELs is not considered. Together, they lead to the following three scenarios: The bank conducts only WMPs and its magnitude of scope equities is $S E_{M 0}$; the bank conducts only ELs and its magnitude of scope equity is $S E_{0 Q}$; and the bank gets involved in both the shadow banking activities and its magnitude of scope equity is $S E_{M Q}$. Equations (6)-(8) measure the relative increase in equity that would result from a splintering of the bank's risk-adjusted equity when $M=0$ and $Q=0$ into the risk-adjusted equities of the three alternatives. Such a fragmentation of the bank increases, decreases, or remains unchanged as the magnitude of scope equities is greater than, less than, or equal to zero, respectively.

\section{Solving the Model}

After a presentation of the model setting, we are now ready to solve the bank's optimal choice of $R_{L}$. Partially differentiating (3) with respect to $R_{L}$, the first-order condition is given by:

$$
\frac{\partial D O C}{\partial R_{L}}=\frac{\partial S C}{\partial R_{L}}-\frac{\partial D I C}{\partial R_{L}}=0,
$$

where we require that the second-order condition be satisfied, $\partial^{2} D O C / \partial R_{L}^{2}<0$. The term $\partial S C / \partial R_{L}$ in (9) can be explained as the marginal equity value of loan rate in the standard call option valuation. The term $\partial D I C / \partial R_{L}$ can be explained as the marginal debt value in the DIC option valuation. The optimal loan rate is determined where both the marginal values are equal.

Having examined the solution to the bank's optimization problem, we will derive the following three sets of comparative static results in order to discuss the issues mentioned in the Introduction. First, we consider the impact on optimal bank interest margin from changes in WMPs, ELs, the barrier, and the capital-to-deposits ratio. Implicit differentiation of (9) with respect to $M, Q, \beta$, and $q$ yields:

$$
\frac{\partial R_{L}}{\partial P}=-\frac{\partial^{2} D O C}{\partial R_{L} \partial P} / \frac{\partial^{2} D O C}{\partial R_{L}^{2}}
$$

where

$$
P=M, Q, \beta, \text { or } q .
$$


Second, we consider the impact on the bank's liability evaluated at the optimal loan rate from changes in WMPs, ELs, the barrier, and the capital-to-deposits ratio. Differentiation of (4) with respect to $M, Q, \beta$, and $q$ yields:

$$
\frac{d L i a}{d P}=\frac{\partial L i a}{\partial P}+\frac{\partial L i a}{\partial R_{L}} \frac{\partial R_{L}}{\partial P},
$$

where

$$
P=M, Q, \beta, \text { or } q .
$$

In (11), the first term on the right-hand side can be interpreted as the direct effect, while the second term can be interpreted as the indirect effect. The direct effect captures the change in the bank's liability value due to an increase in one parameter, holding the optimal loan rate constant. The indirect effect arises because an increase in the parameter changes the bank's liability value through the loan rate adjustment in every possible state.

Third, we consider the impact on the magnitude of the bank's scope equities from changes in the barrier, and the capital-to-deposits ratio at various levels of WMPs and/or ELs. Differentiation of (6)-(8) with respect to $\beta$, and $q$ yields:

$$
\begin{gathered}
\frac{d S E_{M 0}}{d P}=\frac{\partial S E_{M 0}}{\partial P}+\frac{\partial S E_{M 0}}{\partial R_{L}} \frac{\partial R_{L}}{\partial P}, \\
\frac{d S E_{0 Q}}{d P}=\frac{\partial S E_{0 Q}}{\partial P}+\frac{\partial S E_{0 Q}}{\partial R_{L}} \frac{\partial R_{L}}{\partial P}, \\
\frac{d S E_{M Q}}{d P}=\frac{\partial S E_{M Q}}{\partial P}+\frac{\partial S E_{M Q}}{\partial R_{L}} \frac{\partial R_{L}}{\partial P},
\end{gathered}
$$

where

$$
P=\beta \text { or } q .
$$

It is recognized that the added complexity of the barrier option theory of corporate security valuation of a bank does not always lead to clear-cut results in (10)-(14). But we can speak of tendencies for reasonable numerical parameter levels corresponding roughly to a hypothetical bank. We argue that the formulas for the values of the equity claims, the liability, and the scope equities presented in the previous section are truly closed formulas that can be readily implemented once the relevant parameter levels are given. Toward that end, a numerical exercise is designed to analyze the comparative static estimates in the following section.

\section{Numerical Analysis}

In the numerical analysis, we first present the baseline parameter constellations for (3) and (5). Second, for each result, we discuss the procedure used to obtain it. Third, we demonstrate the key results and provide the intuition for each finding.

\subsection{Parameter Basics}

Unless otherwise indicated, a more tractable scenario assumes that the parameter levels are $R=4.0 \%, R_{M}=5.0 \%, R_{P}=3.5 \%, R_{Q}=5.0 \%, R_{D}=3.0 \%, K=28, m=0.2 \%, \alpha=0.3$, and $\sigma=0.3$. Let $\left(R_{L}(\%), L\right)$ change from $(5.1,350)$ to $(5.7,329)$ based on the condition of $\partial L / \partial R_{L}<0$; let $M$ increase from 70 to 82 ; let $Q$ increase from 70 to 82 ; let $\beta$ increase from 0.65 to 0.90 ; and let $q$ increase from $8.2 \%$ to $9.4 \%$. The assumed numerical values are explained as follows:

(i) The conditions of $R_{L}>R$, and $R>R_{D}$ indicate the scope for earning-asset portfolio substitution (Kashyap et al. 2002), and the case of the binding capital constraint (Wong 1997), respectively. Accordingly, we have the result of $R_{L}>R_{D}$, yielding a positive value of the bank interest margin recognized as a primary element of earnings (Saunders and Schumacher 2000). 
(ii) The condition of $R_{M}>R$ implies that WMPs are risky in that they are subject to non-performance. Further, Lu et al. (2015) point out that about $97 \%$ of WMPs have a maturity of less than one year. Accordingly, the condition of $R_{L}>R_{M}$ is assumed in the numerical analysis. The condition of $R_{P}>R_{D}$ demonstrates that WMPs attract investors who expect a higher return than is available on deposits at banks (Lu et al. 2015). In addition, we assume $\alpha=0.3$ since banks cannot invest funds in non-standard assets that exceed 35\% of the value of their outstanding WMPs (Lu et al. 2015).

(iii) The assumed condition of $R_{Q}>R$ explains that the amount of ELs is lent through the bank to the borrower at $R_{Q}$ as instructed by the trustor. ELs are risky in that they are subject to non-performance.

(iv) The premium for the shadow banking entrusted lending service as well as its risk compensation is assumed to be $m=0.2 \%$ of ELs.

(v) The specification of capital adequacy requirement is consistent with the Basel, which is set by the capital-to-deposits ratio $q=K / D=28 / D=8.2 \%$. In this case, a capital-to-asset ratio at $t=0$ is $K / L=28 / 350=8.0 \%$, which meets the requirement (VanHoose 2007).

(vi) We assume $\sigma=0.3$ due to the empirical findings of Brockman and Turtle (2003): the mean value of asset volatility is 0.2904 with a corresponding standard deviation of 0.2608 in the descriptive sample statistics for firms.

(vii) We assume $\beta=0.65$ in the numerical analysis according to Brockman and Turtle (2003): the mean value of barrier is 0.6920 with a corresponding standard deviation of 0.2259 in the pooled sample statistics for firms.

In the following, we consider the effects on the optimal loan rate (and thus the optimal bank interest margin), bank liabilities, and scope equities from changes in the parameters of the model.

\subsection{Impacts on Bank Interest Margin}

As mentioned previously, (3) is a contingent claim model for the valuation of the bank's equity where default can occur at any time before the maturity date. A simulation exercise shown in Table 1 demonstrates that market-based estimates of bank equity evaluated at the optimal bank interest margin which ignore the premature default lead to overestimation. This is because the computed DIC values observed from Table 1 are consistently positive in sign. This result is consistent with the empirical findings of Episcopos (2008). Moreover, we observe that the value of the bank's equity (the term SC in (3)), represented by a European call in the standard contingent model, is split between the equity value of DOC (shown in the first panel of Table 1) and the FDIC's contingent asset of DIC value (shown in the second panel).

We further consider the impact on the bank's interest margin from changes in the WMPs based on (10) where $P=M$. The finding is shown in the last panel of Table 1 that an increase in the amount of WMPs decreases the bank's interest margin. Intuitively, as the bank decides to increase its WMPs, it must now provide a return to a larger fund base. One way the bank may attempt to augment its total returns is by shifting its investments to its loans and away from the liquid-asset markets. If loan demand is relatively rate-elastic, a larger loan portfolio is possible at a reduced margin. In explanation of deteriorating bank interest margins, we show a strong focus on shadow banking activities. Shadow banking activities as such make the bank more prone to loan risk-taking, thereby adversely affecting banking stability. We provide a possible explanation for the argument of Adrian and Ashcraft (2012): the shadow banking system collapsed during the financial crisis of 2007-2009.

It is interesting to consider the impact on bank interest margin from changes in the ELs based on (10) where $P=Q$. The finding in Table 2 shows that an increase in the amount of ELs decreases the bank's interest margin. The same interpretation as previously discussed applies. Basically, increases in shadow banking entrusted loan activities encourage the bank to shift investments to its loan portfolio 
from other earning assets such as bonds. In an imperfect loan market, the bank must reduce its margin in order to increase the amount of risky loans.

Table 1. Responsiveness of bank interest margin to WMPs ${ }^{1}$.

\begin{tabular}{|c|c|c|c|c|c|c|c|}
\hline \multirow[b]{2}{*}{$M$} & \multicolumn{7}{|c|}{$\left(R_{L} \%, L\right)$} \\
\hline & $(5.1,350)$ & $(5.2,349)$ & $(5.3,347)$ & $(5.4,344)$ & $(5.5,340)$ & $(5.6,335)$ & $(5.7,329)$ \\
\hline & \multicolumn{7}{|c|}{ DOC } \\
\hline 70 & 75.9410 & 76.0466 & 76.0189 & 75.8561 & 75.5564 & 75.1182 & 74.5399 \\
\hline 72 & 76.0249 & 76.1306 & 76.1028 & 75.9399 & 75.6401 & 75.2019 & 74.6235 \\
\hline 74 & 76.1089 & 76.2146 & 76.1867 & 76.0238 & 75.7239 & 75.2856 & 74.7071 \\
\hline 76 & 76.1929 & 76.2985 & 76.2706 & 76.1076 & 75.8077 & 75.3693 & 74.7907 \\
\hline 78 & 76.2769 & 76.3825 & 76.3546 & 76.1915 & 75.8915 & 75.4530 & 74.8744 \\
\hline 80 & 76.3610 & 76.4664 & 76.4385 & 76.2753 & 75.9753 & 75.5367 & 74.9580 \\
\hline \multirow[t]{2}{*}{82} & 76.4450 & 76.5504 & 76.5224 & 76.3592 & 76.0591 & 75.6204 & 75.0416 \\
\hline & \multicolumn{7}{|c|}{$\operatorname{DIC}(\%)$} \\
\hline 70 & 2.9491 & 2.9098 & 2.8581 & 2.7944 & 2.7193 & 2.6332 & 2.5367 \\
\hline 72 & 2.9561 & 2.9168 & 2.8651 & 2.8014 & 2.7262 & 2.6401 & 2.5435 \\
\hline 74 & 2.9632 & 2.9238 & 2.8721 & 2.8083 & 2.7331 & 2.6469 & 2.5502 \\
\hline 76 & 2.9703 & 2.9309 & 2.8791 & 2.8153 & 2.7400 & 2.6538 & 2.5570 \\
\hline 78 & 2.9774 & 2.9379 & 2.8861 & 2.8223 & 2.7469 & 2.6606 & 2.5638 \\
\hline 80 & 2.9844 & 2.9450 & 2.8931 & 2.8292 & 2.7539 & 2.6675 & 2.5706 \\
\hline \multirow[t]{2}{*}{82} & 2.9915 & 2.9520 & 2.9001 & 2.8362 & 2.7608 & 2.6743 & 2.5774 \\
\hline & \multicolumn{7}{|c|}{$\partial R_{L} / \partial M\left(10^{-5}\right)$} \\
\hline $70 \rightarrow 72$ & - & -1.5507 & -1.8446 & -2.1526 & -2.4820 & -2.8407 & - \\
\hline $72 \rightarrow 74$ & - & -1.5461 & -1.8388 & -2.1456 & -2.4736 & -2.8308 & - \\
\hline $74 \rightarrow 76$ & - & -1.5416 & -1.8331 & -2.1386 & -2.4653 & -2.8209 & - \\
\hline $76 \rightarrow 78$ & - & -1.5371 & -1.8274 & -2.1317 & -2.4569 & -2.8110 & - \\
\hline $78 \rightarrow 80$ & - & -1.5325 & -1.8217 & -2.1248 & -2.4487 & -2.8011 & - \\
\hline $80 \rightarrow 82$ & - & -1.5280 & -1.8161 & -2.1179 & -2.4404 & -2.7914 & - \\
\hline
\end{tabular}

${ }^{1}$ Parameter values, unless stated otherwise, $R=4.0 \%, R_{M}=5.0 \%, R_{P}=3.5 \%, R_{Q}=5.0 \%, R_{D}=3.0 \%, K=28$, $m=0.2 \%, \alpha=0.3, \sigma=0.3, Q=70, q=8.2 \%$, and $\beta=0.65$. We obtain the computed results of $\partial^{2} D O C / \partial R_{L}^{2}<0$, which confirms the second-order condition of (9). The values in the shaded areas are computed based on an approximate optimal loan rate of $5.2 \%$ with the equilibrium condition of (9).

Table 2. Responsiveness of bank interest margin to ELs ${ }^{1}$.

\begin{tabular}{|c|c|c|c|c|c|c|c|}
\hline \multirow[b]{2}{*}{$Q$} & \multicolumn{7}{|c|}{$\left(R_{L} \%, L\right)$} \\
\hline & $(5.1,350)$ & $(5.2,349)$ & $(5.3,347)$ & $(5.4,344)$ & $(5.5,340)$ & $(5.6,335)$ & $(5.7,329)$ \\
\hline & \multicolumn{7}{|c|}{$\partial R_{L} / \partial Q\left(10^{-5}\right)$} \\
\hline $70 \rightarrow 72$ & - & -7.3489 & -8.6955 & -10.0881 & -11.5566 & -13.1342 & - \\
\hline $72 \rightarrow 74$ & - & -7.2747 & -8.6012 & -9.9724 & -11.4177 & -12.9694 & - \\
\hline $74 \rightarrow 76$ & - & -7.2015 & -8.5083 & -9.8586 & -11.2811 & -12.8076 & - \\
\hline $76 \rightarrow 78$ & - & -7.1295 & -8.4169 & -9.7467 & -11.1469 & -12.6487 & - \\
\hline $78 \rightarrow 80$ & - & -7.0585 & -8.3269 & -9.6366 & -11.0150 & -12.4925 & - \\
\hline $80 \rightarrow 82$ & - & -6.9886 & -8.2383 & -9.5283 & -10.8853 & -12.3391 & - \\
\hline
\end{tabular}

${ }^{1}$ Parameter values, unless stated otherwise, $R=4.0 \%, R_{M}=5.0 \%, R_{P}=3.5 \%, R_{Q}=5.0 \%, R_{D}=3.0 \%, K=28$, $m=0.2 \%, \alpha=0.3, \sigma=0.3, M=70, q=8.2 \%$, and $\beta=0.65$. We obtain the computed results of $\partial^{2} D O C / \partial R_{L}^{2}<0$, which confirms the second-order condition of (9). The values in the shaded areas are computed based on an approximate optimal loan rate of $5.2 \%$ with the equilibrium condition of (9).

An interesting result observed from Table 3 is that, as the barrier is raised, the bank's interest margin is increased. Since the bank is forced to increase the barrier, it must now provide a return to a higher DIC value (and thus a lower DOC value) base. One way the bank may attempt to augment its total equity is by shifting its investments from its loan portfolio to the liquid-asset markets at an 
increased margin. A barrier as such makes the bank more prudent and less prone to loan risk-taking. Episcopos (2008) concludes that raising the barrier induces a wealth transfer from bank shareholders to the FDIC, implying better protection of the deposit insurance fund. In addition, the very existence of the barrier tends to reduce shareholder incentive to take more risk. We restate our result above that an increase in the insurance fund protection by the FIDC makes the bank more prudent to loan risk-taking at an increased margin. Our finding is largely supported by Episcopos (2008).

Table 3. Responsiveness of bank interest margin to barrier ${ }^{1}$.

\begin{tabular}{cccccccc}
\hline \multicolumn{7}{c}{$\left(\boldsymbol{R}_{\mathbf{L}} \mathbf{\%}, \boldsymbol{L}\right)$} \\
\hline \multicolumn{10}{c}{$\mathbf{( 5 . 1 , 3 5 0 )}$} & $\mathbf{( 5 . 2 , 3 4 9 )}$ & $\mathbf{( 5 . 3 , 3 4 7 )}$ & $\mathbf{( 5 . 4 , 3 4 4 )}$ & $\mathbf{( 5 . 5 , 3 4 0 )}$ & $\mathbf{( 5 . 6 , 3 3 5 )}$ & $\mathbf{( 5 . 7 , 3 2 9 )}$ \\
\hline $0.65 \rightarrow 0.70$ & - & 0.0233 & 0.0308 & 0.0379 & 0.0446 & 0.0509 & - \\
$0.70 \rightarrow 0.75$ & - & 0.0778 & 0.1045 & 0.1299 & 0.1539 & 0.1767 & - \\
$0.75 \rightarrow 0.80$ & - & 0.2004 & 0.2742 & 0.3445 & 0.4115 & 0.4753 & - \\
$0.80 \rightarrow 0.85$ & - & 0.4242 & 0.5922 & 0.7524 & 0.9053 & 1.0511 & - \\
$0.85 \rightarrow 0.90$ & - & 0.7883 & 1.1239 & 1.4431 & 1.7469 & 2.0361 & - \\
$0.90 \rightarrow 0.95$ & - & 1.3968 & 2.0324 & 2.6306 & 3.1939 & 3.7250 & -
\end{tabular}

1 Parameter values, unless stated otherwise, $R=4.0 \%, R_{M}=5.0 \%, R_{P}=3.5 \%, R_{Q}=5.0 \%, R_{D}=3.0 \%, K=28$, $m=0.2 \%, \alpha=0.3, \sigma=0.3, M=70, Q=70$, and $q=8.2 \%$. We obtain the computed results of $\partial^{2} D O C / \partial R_{L}^{2}<0$, which confirms the second-order condition of (9). The values in the shaded areas are computed based on an approximate optimal loan rate of $5.2 \%$ with the equilibrium condition of (9).

We also consider the impact on the bank's interest margin from changes in the capital-to-deposits ratio based on (10) where $P=q$. The result is concluded in Table 4 that an increase in the capital-to-deposits ratio decreases the bank's interest margin. The intuition is very straightforward. When the bank is forced to increase its capital relative to its deposits, it must now provide a return to a larger equity capital base. A possible way for the bank to augment its total returns is by shifting its investments from the liquid assets to the loan portfolio at a reduced margin. Our result is at large consistent with the empirical finding that low interest rate levels increase bank risk-taking substantially. ${ }^{12}$

Table 4. Responsiveness of bank interest margin to capital-to-deposits ratio ${ }^{1}$.

\begin{tabular}{cccccccc}
\hline \multicolumn{7}{c}{$\left(\boldsymbol{R}_{\mathbf{L}} \mathbf{\%}, \mathbf{L}\right)$} \\
\hline $\boldsymbol{q} \mathbf{( \% )}$ & $\mathbf{( 5 . 1 , 3 5 0 )}$ & $\mathbf{( 5 . 2 , 3 4 9 )}$ & $\mathbf{( 5 . 3 , 3 4 7 )}$ & $\mathbf{( 5 . 4 , 3 4 4 )}$ & $\mathbf{( 5 . 5 , 3 4 0 )}$ & $\mathbf{( 5 . 6 , 3 3 5 )}$ & $\mathbf{( 5 . 7 , 3 2 9 )}$ \\
\hline \multicolumn{7}{c}{$\partial R_{L} / \partial q\left(10^{-4}\right)$} \\
$8.2 \rightarrow 8.4$ & - & -3.6393 & -4.2566 & -4.8724 & -5.4972 & -6.1420 & - \\
$8.4 \rightarrow 8.6$ & - & -3.4682 & -4.0550 & -4.6405 & -5.2344 & -5.8474 & - \\
$8.6 \rightarrow 8.8$ & - & -3.3088 & -3.8675 & -4.4247 & -4.9901 & -5.5735 & - \\
$9.0 \rightarrow 9.0$ & - & -3.1602 & -3.6926 & -4.2237 & -4.7625 & -5.3185 & - \\
$9.2 \rightarrow 9.4$ & - & -3.0214 & -3.5293 & -4.0360 & -4.5500 & -5.0805 & - \\
\hline
\end{tabular}

${ }^{1}$ Parameter values, unless stated otherwise, $R=4.0 \%, R_{M}=5.0 \%, R_{P}=3.5 \%, R_{Q}=5.0 \%, R_{D}=3.0 \%, K=28$, $m=0.2 \%, \alpha=0.3, \sigma=0.3, M=70, Q=70$, and $\beta=0.65$. We obtain the computed results of $\partial^{2} D O C / \partial R_{L}^{2}<0$, which confirms the second-order condition of (9). The values in the shaded areas are computed based on an approximate optimal loan rate of $5.2 \%$ with the equilibrium condition of (9).

12 Van Riet (2017) offers a review of the effects of ultra-low interest rates in the euro area. The author points out that the ECB and the European micro- and macro-prudential authorities remained watchful of the unintended side-effects of an extended period of very low or negative interest rates for financial intermediation, financial stability and market discipline, and took preventive or corrective measures as appropriate. 


\subsection{Impacts on Bank Liabilities}

The following analyses demonstrate the comparative static results of the bank's liabilities with respect to WMPs, ELs, $\beta$ and $q$ based on (11).

First, the computed results presented in Table 5 state that an increase in WMPs increases the liabilities of the bank. The direct effect captures the change in the bank's liabilities due to an increase in the WMPs, holding the optimal loan rate constant. It is unambiguously positive because an increase in the WMPs increases the bank's liabilities. This is because WMPs are usually purchased by relatively wealthy investors as substitutes for bank deposits, with the benefit of higher yields than banks are allowed to offer on formal deposits (Elliott et al. 2015). The indirect effect arises because (i) an increase in the WMPs decreases the optimal loan rate as mentioned previously, and (ii) further an increase in the amount of loans at a reduced loan rate increases the bank's liabilities since increased assets are funded. Overall, the involvement of the WMPs brings higher liabilities for the bank. As the WMPs increase, liabilities behave more like equity and equity converges to zero. Given current regulation statutes, it is safe to say that the value of liabilities, Lia, is in the hands of the FDIC treated as a receiver. It is reasonable to argue that an increase in the WMPs held by the bank results in increasing the bank's liabilities since the WMPs are largely unregulated, hence deteriorating banking stability.

Table 5. Responsiveness of the bank's liabilities to WMPs ${ }^{1}$.

\begin{tabular}{|c|c|c|c|c|c|c|c|}
\hline \multirow[b]{2}{*}{$M$} & \multicolumn{7}{|c|}{$\left(R_{L} \%, L\right)$} \\
\hline & $(5.1,350)$ & $(5.2,349)$ & $(5.3,347)$ & $(5.4,344)$ & $(5.5,340)$ & $(5.6,335)$ & $(5.7,329)$ \\
\hline & \multicolumn{7}{|c|}{ Lia } \\
\hline 70 & 387.4590 & 386.6514 & 384.9221 & 382.2699 & 378.6936 & 374.1918 & 368.7631 \\
\hline 72 & 388.0051 & 387.1974 & 385.4682 & 382.8161 & 379.2399 & 374.7381 & 369.3095 \\
\hline 74 & 388.5511 & 387.7434 & 386.0143 & 383.3622 & 379.7861 & 375.2844 & 369.8559 \\
\hline 76 & 389.0971 & 388.2895 & 386.5604 & 383.9084 & 380.3323 & 375.8307 & 370.4023 \\
\hline 78 & 389.6431 & 388.8355 & 387.1064 & 384.4545 & 380.8785 & 376.3770 & 370.9486 \\
\hline 80 & 390.1890 & 389.3816 & 387.6525 & 385.0007 & 381.4247 & 376.9233 & 371.4950 \\
\hline \multirow[t]{2}{*}{82} & 390.7350 & 389.9276 & 388.1986 & 385.5468 & 381.9709 & 377.4696 & 372.0414 \\
\hline & \multicolumn{7}{|c|}{$d L i a / d M$ : total effect (\%) } \\
\hline $70 \rightarrow 72$ & - & 27.3150 & 27.3368 & 27.3650 & 27.4001 & 27.4432 & - \\
\hline $72 \rightarrow 74$ & - & 27.3147 & 27.3365 & 27.3646 & 27.3996 & 27.4425 & - \\
\hline $74 \rightarrow 76$ & - & 27.3145 & 27.3362 & 27.3642 & 27.3990 & 27.4418 & - \\
\hline $76 \rightarrow 78$ & - & 27.3143 & 27.3360 & 27.3638 & 27.3985 & 27.4412 & - \\
\hline $78 \rightarrow 80$ & - & 27.3141 & 27.3357 & 27.3634 & 27.3980 & 27.4405 & - \\
\hline $80 \rightarrow 82$ & - & 27.3139 & 27.3354 & 27.3630 & 27.3975 & 27.4398 & - \\
\hline
\end{tabular}

1 Parameter values, unless stated otherwise, $R=4.0 \%, R_{M}=5.0 \%, R_{P}=3.5 \%, R_{Q}=5.0 \%, R_{D}=3.0 \%, K=28$, $m=0.2 \%, \alpha=0.3, \sigma=0.3, Q=70, q=8.2 \%$, and $\beta=0.65$. Both the direct effect $\partial$ Lia $/ \partial M$ and the indirect effect $\left(\partial \mathrm{Lia} / \partial R_{L}\right)\left(\partial R_{L} / \partial M\right)$ are consistently positive in sign. The values in the shaded areas are computed based on an approximate optimal loan rate of $5.2 \%$ with the equilibrium condition of (9).

We show the following result based on the computed results observed from Table 6: an increase in the ELs results in increasing the bank's liabilities. The interpretation of this result follows a similar argument as in the case of a change in ELs. Basically, an increase in the ELs increases the bank's loans at a reduced loan rate set by the bank, and further increases the cost of funding (the liabilities) to meet an increased loan investment. In addition, an increase in the ELs directly increases the liabilities of the bank. Overall, an increase in the ELs results in increasing the bank's debt burden. 
Table 6. Responsiveness of the bank's liabilities to ELs ${ }^{1}$.

\begin{tabular}{|c|c|c|c|c|c|c|c|}
\hline \multirow[b]{2}{*}{$Q$} & \multicolumn{7}{|c|}{$\left(R_{L} \%, L\right)$} \\
\hline & $(5.1,350)$ & $(5.2,349)$ & $(5.3,347)$ & $(5.4,344)$ & $(5.5,340)$ & $(5.6,335)$ & $(5.7,329)$ \\
\hline & \multicolumn{7}{|c|}{$d$ Lia / $d Q$ : total effect (\%) } \\
\hline $70 \rightarrow 72$ & - & 92.4484 & 92.5512 & 92.6822 & 92.8439 & 93.0403 & - \\
\hline $72 \rightarrow 74$ & - & 92.4437 & 92.5453 & 92.6747 & 92.8344 & 93.0281 & - \\
\hline $74 \rightarrow 76$ & - & 92.4391 & 92.5395 & 92.6673 & 92.8249 & 93.0160 & - \\
\hline $76 \rightarrow 78$ & - & 92.4345 & 92.5338 & 92.6601 & 92.8156 & 93.0041 & - \\
\hline $78 \rightarrow 80$ & - & 92.4299 & 92.5282 & 92.6529 & 92.8065 & 92.9925 & - \\
\hline $80 \rightarrow 82$ & - & 92.4255 & 92.5226 & 92.6459 & 92.7975 & 92.9810 & - \\
\hline
\end{tabular}

${ }^{1}$ Parameter values, unless stated otherwise, $R=4.0 \%, R_{M}=5.0 \%, R_{P}=3.5 \%, R_{Q}=5.0 \%, R_{D}=3.0 \%, K=28$, $m=0.2 \%, \alpha=0.3, \sigma=0.3, M=70, q=8.2 \%$, and $\beta=0.65$. Both the direct effect $\partial$ Lia $/ \partial Q$ and the indirect effect $\left(\partial \mathrm{Lia} / \partial R_{L}\right)\left(\partial R_{L} / \partial Q\right)$ are consistently positive in sign. The values in the shaded areas are computed based on an approximate optimal loan rate of $5.2 \%$ with the equilibrium condition of (9).

The result observed from Table 7 is illustrated as follows. An increase in the barrier results in increasing the liabilities of the bank. An interesting result, as mentioned previously, is that, as the barrier is raised, the value of the $S C$ equity is not affected although the value of the DOC equity is reduced, while the FDIC's contingent asset value is increased by the same amount. Thus, raising the barrier induces a transfer of wealth from shareholders to the FDIC, implying better protection of the insurance fund (i.e., increasing the bank's liabilities in our model).

Table 7. Responsiveness of the bank's liabilities to barrier ${ }^{1}$.

\begin{tabular}{|c|c|c|c|c|c|c|c|}
\hline \multirow[b]{2}{*}{$\beta$} & \multicolumn{7}{|c|}{$\left(R_{L} \%, L\right)$} \\
\hline & $(5.1,350)$ & $(5.2,349)$ & $(5.3,347)$ & $(5.4,344)$ & $(5.5,340)$ & $(5.6,335)$ & $(5.7,329)$ \\
\hline & \multicolumn{7}{|c|}{$d L i a / d \beta$ : total effect } \\
\hline $0.65 \rightarrow 0.70$ & - & 2.4375 & 2.0512 & 1.5269 & 0.8756 & 0.1082 & - \\
\hline $0.70 \rightarrow 0.75$ & - & 9.1755 & 7.8551 & 6.0397 & 3.7650 & 1.0654 & - \\
\hline $0.75 \rightarrow 0.80$ & - & 26.4758 & 22.9773 & 18.1037 & 11.9464 & 4.5922 & - \\
\hline $0.80 \rightarrow 0.85$ & - & 61.2937 & 53.6450 & 42.8554 & 29.1264 & 12.6479 & - \\
\hline $0.85 \rightarrow 0.90$ & - & 118.0878 & 103.3400 & 82.3128 & 55.4322 & 23.0933 & - \\
\hline $0.90 \rightarrow 0.95$ & - & 194.7443 & 167.5357 & 128.5150 & 78.6576 & 18.8461 & - \\
\hline
\end{tabular}

1 Parameter values, unless stated otherwise, $R=4.0 \%, R_{M}=5.0 \%, R_{P}=3.5 \%, R_{Q}=5.0 \%, R_{D}=3.0 \%, K=28$, $m=0.2 \%, \alpha=0.3, \sigma=0.3, M=70, Q=70$, and $q=8.2 \%$. The direct effect $\partial$ Lia $/ \partial \beta$ is consistently positive in sign, while the indirect effect $\left(\partial L i a / \partial R_{L}\right)\left(\partial R_{L} / \partial \beta\right)$ is consistently negative in sign. The indirect effect is insufficient to offset the direct effect. The values in the shaded areas are computed based on an approximate optimal loan rate of $5.2 \%$ with the equilibrium condition of (9).

Table 8 demonstrates that the capital-to-deposits ratio enhances the bank's liabilities. Intuitively, as the bank is forced to increase its capital relative to its deposit level, it must now provide a return to a larger equity base (and hence a higher level of liabilities). This is captured by the direct effect. Furthermore, one way the bank may attempt to augment its total returns is by shifting its investments to its loans and away from the liquid-asset market at a reduced interest margin. This is captured by the indirect effect since $\partial L i a / \partial R_{L}<0$ and $\partial R_{L} / \partial q<0$. The positive direct effect is reinforced by the indirect effect, yielding that an increase in the capital-to-deposits ratio increases the bank's liabilities. This paper suggests that capital deregulation should be conducted by the government in order to decrease the bank's liabilities, and hence to increase the bank's survival probability, which is consistent with the findings of Repullo (2004). 
Table 8. Responsiveness of the bank's liabilities to capital-to-deposits ratio ${ }^{1}$.

\begin{tabular}{cccccccc}
\hline \multicolumn{7}{c}{$\left(\boldsymbol{R}_{L} \mathbf{\%}, \mathbf{L}\right)$} \\
\hline $\boldsymbol{q} \mathbf{( \% )}$ & $\mathbf{( 5 . 1 , 3 5 0 )}$ & $\mathbf{( 5 . 2 , 3 4 9 )}$ & $\mathbf{( 5 . 3 , 3 4 7 )}$ & $\mathbf{( 5 . 4 , 3 4 4 )}$ & $\mathbf{( 5 . 5 , 3 4 0 )}$ & $\mathbf{( 5 . 6 , 3 3 5 )}$ & $\mathbf{( 5 . 7 , 3 2 9 )}$ \\
\hline \multicolumn{7}{c}{$d L i a / d q:$ total effect } \\
\hline $8.2 \rightarrow 8.4$ & - & 0.2308 & 0.2358 & 0.2420 & 0.2495 & 0.2583 & - \\
$8.6 \rightarrow 8.6$ & - & 0.2199 & 0.2247 & 0.2306 & 0.2378 & 0.2462 & - \\
$8.8 \rightarrow 9.8$ & - & 0.2099 & 0.2144 & 0.2200 & 0.2268 & 0.2349 & - \\
$9.0 \rightarrow 9.2$ & - & 0.2004 & 0.2048 & 0.2102 & 0.2167 & 0.2243 & - \\
$9.2 \rightarrow 9.4$ & - & 0.1917 & 0.1958 & 0.2010 & 0.2071 & 0.2145 & - \\
& - & 0.1834 & 0.1874 & 0.1923 & 0.1982 & 0.2052 & -
\end{tabular}

${ }^{1}$ Parameter values, unless stated otherwise, $R=4.0 \%, R_{M}=5.0 \%, R_{P}=3.5 \%, R_{Q}=5.0 \%, R_{D}=3.0 \%, K=28$, $m=0.2 \%, \alpha=0.3, \sigma=0.3, M=70, Q=70$, and $\beta=0.65$. Both the direct effect $\partial$ Lia $/ \partial q$ and the indirect effect $\left(\partial \mathrm{Lia} / \partial R_{L}\right)\left(\partial R_{L} / \partial q\right)$ are consistently positive in sign. The values in the shaded areas are computed based on an approximate optimal loan rate of $5.2 \%$ with the equilibrium condition of (9).

\subsection{Impacts on Bank Scope Equities}

It is necessary to elaborate on the issue of scope equities. Here, consider the impacts on the bank's scope equities based on (12)-(14) where $P=\beta$. Based on the local solutions evaluated at their own optimal loan rate, which is observed from the upper panel in Table 9, we obtain the inequality of $0<S E_{M 0}<S E_{0 Q}<S E_{M Q}$ at various levels of the barrier. The inequality demonstrates that the scope equities are larger when the bank gets involved in multiple shadow banking activities than when the bank gets involved in a single shadow banking activity. Accordingly, we show that the multiple shadow banking diversification of bank loan portfolio is equity value-enhancing to the bank. Further, the comparative static results observed from the lower panel of Table 9 indicate that an increase in the barrier decreases, significantly in the case of multiple shadow banking activities, the scope equity of the bank. Raising the barrier induces a transfer of wealth from shareholders to the FDIC, implying better protection of the insurance fund, and hence leading to a decrease of the bank's scope equities from the multiple shadow banking diversification.

Table 9. Responsiveness of the bank's scope equities to barrier at various levels of WMPs and/or ELs ${ }^{1}$.

\begin{tabular}{cccc}
\hline \multicolumn{1}{c}{$\boldsymbol{\beta}$} & $S E_{M \mathbf{0}} \mathbf{( \% )}$ & $S E_{\mathbf{0 Q}} \mathbf{( \% )}$ & $S E_{M Q} \mathbf{( \% )}$ \\
\hline & $(M=70, Q=0)$ & $(M=0, Q=70)$ & $(M=70, Q=70)$ \\
\hline 0.65 & 4.3167 & 11.9456 & 15.3449 \\
0.70 & 4.3082 & 11.9125 & 15.3069 \\
0.75 & 4.2787 & 11.7983 & 15.1761 \\
0.80 & 4.1988 & 11.4917 & 14.8253 \\
0.85 & 4.0201 & 10.8052 & 14.0395 \\
0.90 & 3.6642 & 9.4231 & 12.4533 \\
0.95 & 2.9784 & 6.6817 & 9.2837 \\
\hline & $d S E_{M 0} / d \beta(\%)$ & $d S E_{0 Q} / d \beta(\%)$ & $d S E_{M Q} / d \beta(\%)$ \\
\hline $0.65 \rightarrow 0.70$ & -0.1725 & -0.6690 & -0.7682 \\
$0.70 \rightarrow 0.75$ & -0.5999 & -2.3068 & -2.6435 \\
$0.75 \rightarrow 0.80$ & -1.6188 & -6.1926 & -7.0881 \\
$0.80 \rightarrow 0.85$ & -3.6219 & -13.8610 & -15.8704 \\
$0.85 \rightarrow 0.90$ & -7.2143 & -27.8949 & -32.0316 \\
$0.90 \rightarrow 0.95$ & -13.9107 & -55.3140 & -64.0012 \\
\hline
\end{tabular}

\footnotetext{
${ }^{1}$ Parameter values, unless stated otherwise, $R=4.0 \%, R_{M}=5.0 \%, R_{P}=3.5 \%, R_{Q}=5.0 \%, R_{D}=3.0 \%, K=28$, $m=0.2 \%, \alpha=0.3, \sigma=0.3$, and $q=8.2 \%$. All values are computed based on an approximate optimal loan rate of $5.2 \%$.
}

We also consider the impact on the bank's scope equities based on (12)-(14) where $P=q$. The inequality of $0<S E_{M 0}<S E_{0 Q}<S E_{M Q}$ at various levels of the capital-to-deposits ratio is 
concluded from the observations of the upper panel in Table 10. The result demonstrates that multiple shadow banking diversification may lead to superior return performance for the bank. In addition, we observe the lower panel of Table 10 and show that an increase in the capital-to-deposits ratio consistently increases the bank's scope equities at various levels of WMPs and ELs. In addition, we show that the positive impact on the bank's scope equities from increases in the capital-to-deposits ratio is larger when both WMPs and ELs shadow banking diversification are conducted by the bank than when either WMPs or ELs shadow banking diversification is conducted. Overall, our results are supported by Plantin (2015): tightening capital requirements may spur a surge in shadow banking activities.

Table 10. Responsiveness of the bank's scope equities to capital-to-deposits ratio at various levels of WMPs and ELs ${ }^{1}$.

\begin{tabular}{cccc}
\hline $\boldsymbol{q} \mathbf{( \% )}$ & $S E_{\boldsymbol{M 0}} \mathbf{( \% )}$ & $S E_{\mathbf{0 Q}} \mathbf{( \% )}$ & $S E_{M Q} \mathbf{( \% )}$ \\
\hline 8.2 & $(M=70, Q=0)$ & $(M=0, Q=70)$ & $(M=70, Q=70)$ \\
8.4 & 4.3167 & 11.9456 & 15.3449 \\
8.6 & 4.3205 & 11.9556 & 15.3570 \\
8.8 & 4.3241 & 11.9652 & 15.3685 \\
9.0 & 4.3275 & 11.9744 & 15.3795 \\
9.2 & 4.3308 & 11.9832 & 15.3900 \\
9.4 & 4.3339 & 11.9916 & 15.4001 \\
& 4.3369 & 11.9996 & 15.4097 \\
\hline $8.2 \rightarrow 8.4$ & 1.8822 & 5.0440 & 6.0538 \\
$8.4 \rightarrow 8.6$ & 1.7954 & 4.8108 & 5.7737 \\
$8.6 \rightarrow 8.8$ & 1.7145 & 4.5935 & 5.5127 \\
$8.8 \rightarrow 9.0$ & 1.6389 & 4.3906 & 5.2689 \\
$9.0 \rightarrow 9.2$ & 1.5681 & 4.2008 & 5.0410 \\
$9.2 \rightarrow 9.4$ & 1.5019 & 4.0231 & 4.8275 \\
\hline
\end{tabular}

${ }^{1}$ Parameter values, unless stated otherwise, $R=4.0 \%, R_{M}=5.0 \%, R_{P}=3.5 \%, R_{Q}=5.0 \%, R_{D}=3.0 \%, K=28$, $m=0.2 \%, \alpha=0.3, \sigma=0.3$, and $\beta=0.65$. All values are computed based on an approximate optimal loan rate of $5.2 \%$.

\section{Conclusions}

Guided by the existing theories, this paper theoretically addresses the impacts of shadow banking WMPs and ELs, the barrier-to-debt ratio, and the capital-to-deposits ratio on the optimal bank interest margin, liabilities, and scope equities of the bank. Our four main results are as follows: First, the shadow banking activities of WMPs and ELs and the regulatory capital-to-deposits ratio may be employed to explain the decline in bank interest margins. We find that an increase in WMPs, ELs or regulatory capital-to-deposits ratio significantly decreases the bank's optimal interest margin. Second, WMPs, ELs, barrier, and capital-to-deposits ratio help to enhance the protection of the bank's debtholders. When WMPs, ELs or barrier increases, a wealth transfer from equity holders leads to an increase in liabilities of the bank. An increased capital-to-deposits ratio also enhances the bank's liabilities because the bank must provide a return to a larger equity base and hence a higher level of liabilities. Third, the multiple shadow banking diversification of bank asset portfolio may produce superior return performance but less safety for the bank. The numerical analyses show that the scope equities are larger when the bank gets involved in multiple shadow banking activities than when the bank gets involved in a single shadow banking activity. The multiple shadow banking diversification of bank loan portfolio is equity value-enhancing to the bank. Fourth, tightening capital requirements may spur a surge in shadow banking activities. The positive impact on the bank's scope equities from increases in the capital-to-deposits ratio is larger when both WMPs and ELs shadow banking diversification are conducted by the bank than when either WMPs or ELs shadow banking 
diversification is conducted. The presence of multiple shadow banking activities attenuates the effects of capital regulation on banking stability.

Overall, in the face of the costs that the 2008 banking crisis created for the global economy, a world trend towards imposing heightened capital requirements on traditional banks has emerged. Heightened capital regulation triggers more regulatory arbitrage, thereby inducing a large migration of traditional banking activities toward shadow banking activities. Moreover, the higher solvency of the traditional banking system may then be more than offset by such growth in shadow banking activities. Our results are largely supported by Gorton and Metrick (2010); Adrian and Ashcraft (2012) and Plantin (2015).

Some natural paths for future research emerge. Already mentioned is the fact that macroeconomic factors such as implicit and explicit bank taxation, legal and institutional variables, and business cycle, also affect bank interest margins. This raises the problem of how to avoid insufficient treatment of different barriers, such as structural barrier and Parisian barrier. The model presented here could be extended to include more than one homogeneous class of a constant barrier. With a government as the lender of last resort, we question whether there is little incentive for the bank to pursue sophisticated risk management strategies. We have confirmed the effects of the interaction between shadow banking activities and government intervention on bank performance by constructing a barrier option framework. Introducing different treatments of barrier into the corporate security valuation framework will enrich the answer to the question. This could guide banks to more correct liquidity and risk management based on market value considerations. It would also be straightforward to incorporate leverage risk in shadow banking activities into the model along the line of Plantin (2015).

Author Contributions: All authors collectively contributed to the research strategies of the paper. In personal level, J.-H.L. contributed whole paper but specifically focused on Sections 1, 2 and 6. F.-W.H. developed modeling strategy and hence specifically contributed Sections 3 and 4. Finally, S.C. implemented the numerical analysis and hence specifically contributed Section 5 .

Funding: This research received no external funding.

Acknowledgments: We would like to thank three anonymous referees, and the English editor for their helpful comments and suggestions. The usual disclaimer applies.

Conflicts of Interest: The authors declare no conflicts of interest.

\section{References}

Acharya, Viral V., Iftekhar Hasan, and Anthony Saunders. 2006. Should banks be diversified? Evidence from individual bank loan portfolios. Journal of Business 79: 1355-412. [CrossRef]

Acharya, Viral V., Hamid Mehran, Til Schuermann, and Anjan V. Thakor. 2012. Robust Capital Regulation. Current Issues in Economics and Finance. New York: Federal Reserve Bank of New York, vol. 18, pp. 1-11. Available online: https:/ / www.newyorkfed.org/medialibrary/media/research/current_issues/ci18-4.pdf (accessed on 6 June 2018).

Adrian, Tobias, and Adam B. Ashcraft. 2012. Shadow banking regulation. Annual Review of Financial Economics 4: 99-140. [CrossRef]

Adrian, Tobias, and Hyun Song Shin. 2009. The shadow banking system: Implications for financial regulation. Financial Stability Review; Banque de France, 13, pp. 1-10. Available online: https://publications.banquefrance.fr/sites/default/files/medias/documents / financial-stability-review-13_2009-09.pdf (accessed on 6 June 2018).

Aiyar, Shekhar, Charles W. Calomiris, and Tomasz Wieladek. 2014. Does macro-prudential regulation leak? Evidence from a UK policy experiment. Journal of Money, Credit and Banking 46: 181-214. [CrossRef]

Arnold, Ivo J. M., and Saskia E. van Ewijk. 2012. The quest for growth: The impact of bank strategy on interest margins. International Review of Financial Analysis 25: 18-27. [CrossRef]

Baumol, William J., John C. Panzar, and Robert D. Willig. 1982. Contestable Markets and the Theory of Industry Structure. New York: Harcourt College Pub., ISBN 978-0155139107. 
Berger, Allen N., and Christa H. S. Bouwman. 2013. How does capital affect bank performance during financial crises? Journal of Financial Economics 109: 146-76. [CrossRef]

Black, Fischer, and Myron Scholes. 1973. The pricing of options and corporate liabilities. Journal of Political Economy 81: 637-54. [CrossRef]

Bord, Vitaly M., and João A. C. Santos. 2012. The Rise of the Originate-to-Distribute Model and the Role of Banks in Financial Intermediation. Federal Reserve Bank of New York Economic Policy Review 18: 21-34. Available online: https:/ / www.newyorkfed.org/medialibrary/media/research/epr/12v18n2/1207bord.pdf (accessed on 6 June 2018).

Brockman, Paul, and Harry J. Turtle. 2003. A barrier option framework for corporate security valuation. Journal of Financial Economics 67: 511-29. [CrossRef]

Copeland, Adam. 2012. Evolution and Heterogeneity among Larger Bank Holding Companies: 1994 to 2010. Federal Reserve Bank of New York Economic Policy Review 18: 83-93. Available online: https:/ / www.newyorkfed. $\mathrm{org}$ / medialibrary/media/research/epr/12v18n2/1207cope.pdf (accessed on 6 June 2018).

Diamond, Douglas W. 1984. Financial intermediation and delegated monitoring. Review of Economic Studies 51: 393-414. [CrossRef]

Elliott, Douglas J., Arthur Kroeber, and Qiao Yu. 2015. Shadow Banking in China: A Primer. Economic Studies at Brookings; The Brookings Institution, March. Available online: http:/ /www.brookings.edu/research/ papers / 2015/04/01-shadow-banking-china-primer-elliott-kroeber-yu (accessed on 6 June 2018).

Episcopos, Athanasios. 2008. Bank capital regulation in a barrier option framework. Journal of Banking E Finance 32: 1677-86. [CrossRef]

Funke, Michael, Petar Mihaylovski, and Haibin Zhu. 2015. Monetary Policy Transmission in China: A DSGE Model with Parallel Shadow Banking and Interest Rate Control. In BOFIT Discussion Papers. 9/2015. Helsinki: Bank of Finland, Available online: https:/ /helda.helsinki.fi/bof/bitstream/123456789/13628/2/dp0915_ app \%5b1\%5d.pdf (accessed on 6 June 2018).

Gorton, Gary, and Andrew Metrick. 2010. Regulating the shadow banking system. Brookings Papers on Economic Activity 2010: 261-97. [CrossRef]

Hart, Oliver D., and Luigi Zingales. 2011. Inefficient Provision of Liquidity. NBER Working Paper No. 17299. Cambridge, UK: National Bureau of Economic Research. [CrossRef]

Iftikhar, Syed Faizan. 2015. Financial reforms and financial fragility: A panel data analysis. International Journal of Financial Studies 3: 84-101. [CrossRef]

Jiang, Wei. 2015. The Future of Shadow Banking in China. White Paper. Edited by A. Jerome. New York: Chazen School of International Business, Columbia Business School, Available online: https:/ /ssrn.com/abstract= 2769603 (accessed on 6 June 2018).

Jiménez, Gabriel, Steven Ongena, José-Luis Peydró, and Jesús Saurina. 2017. Macroprudential policy, countercyclical bank capital buffers and credit supply: Evidence from the Spanish dynamic provisioning experiments. Journal of Political Economy 125: 2126-77. [CrossRef]

Kashyap, Anil K., Raghuram G. Rajan, and Jeremy C. Stein. 2002. Banks as liquidity providers: An explanation for the coexistence of lending and deposit-taking. Journal of Finance 57: 33-73. [CrossRef]

Kashyap, Anil K., Raghuram G. Rajan, and Jeremy C. Stein. 2008. Rethinking Capital Regulation. In Maintaining Stability in a Changing Financial System. Kansas City: Federal Reserve Bank of Kansas City, pp. 431-71. Available online: https:/ / www.kansascityfed.org/media/files/publicat/sympos/2008/kashyaprajanstein031209.pdf (accessed on 6 June 2018).

Lepetit, Laetitia, Emmanuelle Nys, Philippe Rous, and Amine Tarazi. 2008. The expansion of services in European banking: Implications for loan pricing and interest margins. Journal of Banking \& Finance 32: 2325-35. [CrossRef]

Li, Xuelian, and Jyh-Horng Lin. 2016. Shadow-banking entrusted loan management, deposit insurance premium, and capital regulation. International Review of Economics \& Finance 41: 98-109. [CrossRef]

Lu, Yunlin, Haifeng Guo, Erin H. Kao, and Hung-Gay Fung. 2015. Shadow banking and firm financing in China. International Review of Economics $\mathcal{E}$ Finance 36: 40-53. [CrossRef]

Mandel, Benjamin H., Donald Morgan, and Chenyang Wei. 2012. The Role of Bank Credit Enhancements in Securitization. Federal Reserve Bank of New York Economic Policy Review 18: 35-46. Available online: https:/ / www.newyorkfed.org/medialibrary/media/research/epr/12v18n2/1207mand.pdf (accessed on 6 June 2018). 
Merton, Robert C. 1973. Theory of rational option pricing. Bell Journal of Economics and Management Science 4: 141-83. [CrossRef]

Merton, Robert C. 1974. On the pricing of corporate debt: The risk structure of interest rates. Journal of Finance 29: 449-70. [CrossRef]

Merton, Robert C. 1977. An analytic derivation of the cost of deposit insurance and loan guarantees. Journal of Banking \& Finance 1: 512-20. [CrossRef]

Osborne, Matthew, Ana-Maria Fuertes, and Alistair Milne. 2012. In good times and in bad: Bank capital ratios and lending rates. International Review of Financial Analysis 51: 102-12. [CrossRef]

Perry, Emily, and Florian Weltewitz. 2015. Wealth Management Products in China; Bulletin, June Quarter 2015; Sydney: Reserve Bank of Australia, pp. 59-68. Available online: https: / /www.rba.gov.au/publications / bulletin/2015/jun/pdf/bu-0615-7.pdf (accessed on 6 June 2018).

Plantin, Guillaume. 2015. Shadow banking and bank capital regulation. Review of Financial Studies 28: 146-75. [CrossRef]

Pozsar, Zoltan. 2008. The Rise and Fall of the Shadow Banking System. Regional Financial Review 44: 13-25. Available online: http:/ / wisburg.com/wp-content/uploads/2017/04/sbs.pdf (accessed on 6 June 2018).

Pozsar, Zoltan, Tobias Adrian, Adam Ashcraft, and Hayley Boesky. 2013. Shadow Banking. Federal Reserve Bank of New York Economic Policy Review 19: 1-16. Available online: https:/ / www.newyorkfed.org/medialibrary/ media/research/epr/2013/0713adri.pdf (accessed on 6 June 2018). [CrossRef]

Rahman, Mohammed Mizanur, Badar Nadeem Ashraf, Changjun Zheng, and Munni Begum. 2017. Impact of cost efficiency on bank capital and the cost of financial intermediation: Evidence from BRICS countries. International Journal of Financial Studies 5: 32. [CrossRef]

Repullo, Rafael. 2004. Capital requirements, market power, and risk-taking in banking. Journal of Financial Intermediation 13: 156-82. [CrossRef]

Ronn, Ehud I., and Avinash K. Verma. 1986. Pricing risk-adjusted deposit insurance: An option-based model. Journal of Finance 41: 871-95. [CrossRef]

Saunders, Anthony, and Liliana Schumacher. 2000. The determinants of bank interest rate margins: An international study. Journal of International Money and Finance 19: 813-32. [CrossRef]

Stiroh, Kevin J., and Adrienne Rumble. 2006. The dark side of diversification: The case of US financial holding companies. Journal of Banking \& Finance 30: 2131-61. [CrossRef]

Valverde, Santiago Carbó, and Francisco Rodríguez Fernández. 2007. The determinants of bank margins in European banking. Journal of Banking $\mathcal{E}$ Finance 31: 2043-63. [CrossRef]

Van Riet, Ad. 2017. The ECB's fight against low inflation: On the effects of ultra-low interest rates. International Journal of Financial Studies 5: 12. [CrossRef]

VanHoose, David. 2007. Theories of bank behavior under capital regulation. Journal of Banking E Finance 31: 3680-97. [CrossRef]

Winton, Andrew. 1999. Don't Put All Your Eggs in One Basket? Diversification and Specialization in Lending. Working Paper. Minneapolis, MN, USA: University of Minnesota. [CrossRef]

Wong, Kit Pong. 1997. On the determinants of bank interest margins under credit and interest rate risks. Journal of Banking \& Finance 21: 251-71. [CrossRef]

Wong, Kit Pong. 2011. Regret theory and the banking firm: The optimal bank interest margin. Economic Modelling 28: 2483-87. [CrossRef]

(C) 2018 by the authors. Licensee MDPI, Basel, Switzerland. This article is an open access article distributed under the terms and conditions of the Creative Commons Attribution (CC BY) license (http:/ / creativecommons.org/licenses/by/4.0/). 